\title{
New data on the Afrotropical Tersilochinae (Hymenoptera, Ichneumonidae)
}

\author{
A.I. Khalaim
}

\section{Новые данные по афротропическим наездникам-терзилохинам (Hymenoptera, Ichneumonidae, Tersilochinae)}

\author{
А.И. Халаим \\ Zoological Institute of the Russian Academy of Sciences, Universitetskaya nab. 1, St. Petersburg, 199034, Russia; \\ Facultad de Ingeniería y Ciencias, Universidad Autónoma de Tamaulipas, Cd. Victoria, Tamaulipas, 87149, México. \\ E-mail: ptera@mail.ru \\ Зоологический институт Российской академии наук, Университетская наб. 1, Санкт-Петербург, 199034, Россия; \\ Факультет инженерии и наук, Автономный университет Тамаулипаса, Сьюдад Виктория, Тамаулипас, 87149, Мексика. \\ E-mail: ptera@mail.ru
}

\begin{abstract}
Three new species belonging to subfamily Tersilochinae are described from the Afrotropical Region: Allophrys budongoana sp. n., Diaparsis (Diaparsis) nebulosa sp. n. and Probles (Euporizon) kipyatkovi sp. n. New data on distribution of Diaparsis (Diaparsis) interstitialis Khalaim, D. (D.) inusitata Khalaim, D. (D.) mostovskii Khalaim, D. (D.) probleformis Khalaim and D. (D.) voluptuosa Khalaim are provided. Male of $D$. (D.) inusitata is recorded for the first time.
\end{abstract}

Key words. Africa, Allophrys, Diaparsis, Euporizon, Probles, taxonomy, new species, new records.

Резюме. Из Афротропической области описаны три новых вида, принадлежащие к подсем. Tersilochinae: Allophrys budongoana sp. n., Diaparsis (Diaparsis) nebulosa sp. n. и Probles (Euporizon) kipyatkovi sp. n. Представлены новые данные о распространении Diaparsis (Diaparsis) interstitialis Khalaim, D. (D.) inusitata Khalaim, D. (D.) mostovskii Khalaim, D. (D.) probleformis Khalaim и D. (D.) voluptuosa Khalaim. Впервые отмечен самец D. (D.) inusitata.

Ключевые слова. Африка, Allophrys, Diaparsis, Euporizon, Probles, систематика, новые виды, новые находки.

\section{Introduction}

Study of the Afrotropical Tersilochinae was started in my previous works, where the genera $\mathrm{He}$ terocola Förster, Meggoleus Townes, Phradis Förster (Khalaim, 2007), Aneuclis Förster (Khalaim, 2009, 2010), Diaparsis Förster (Khalaim, 2013a) and Allophrys Förster (Khalaim, 2013b) were reviewed. Key to genera occurring in the Afrotropical Region was provided in the first paper on Afrotropical Tersilochinae (Khalaim, 2007).

In this paper, three new species of the genera Allophrys, Diaparsis and Probles Förster are described, and a new data on distribution of five recently described species of Diaparsis in Africa is provided. 


\section{Material and methods}

The specimens examined in this study were borrowed from the Natural History Museum, London, UK (further BMNH) and Iziko South African Museum, Cape Town, South Africa (further SAMC). Some specimens are deposited in the collection of the Zoological Institute of the Russian Academy of Sciences, St. Petersburg, Russia (further ZISP).

Photographs were taken at ZISP with a DFC 290 digital camera attached to a Leica MZ16 stereomicroscope; images were combined using Helicon Focus software. Wing venation and morphological terms predominantly follow Townes $(1969,1971)$ with changes according to Khalaim (2011). Countries recorded for the first time in the Distribution section are marked by an asterisk (*).

\section{Taxonomic part}

\section{Allophrys budongoana sp. $\mathbf{n}$.}

(Figs 1-5)

Type material. Holotype: female (BMNH), Uganda, Budongo Forest, 7.II.1935 (F.W. Edwards coll.), "B.M.E.Afr. Exp. B.M.1935-203.”.

Comparison. Differs from the all Afrotropical congeners by the unidentate mandible (Fig. 2, arrow), long malar space, and robust and strongly upcurved ovipositor (Fig. 4). This species is also characterized by the unusually long and strongly compressed metasoma (Fig. 1) with second tergite 3.5 times as long as broad anteriorly.

Description. F e m a le . Body length $3.1 \mathrm{~mm}$. Fore wing length $2.0 \mathrm{~mm}$.

Head rounded behind eye in dorsal view; temple 0.85 times as long as eye width (Fig. 3). Mandible unidentate (Fig. 2, arrow). Clypeus lenticular, mostly smooth, with fine punctures on its upper half. Malar space about 1.3 times as long as basal width of mandible. Flagellum of antenna slender, flagellomeres 2 and 3 about 3.0-3.2 times and subapical flagellomeres 1.6-1.8 times as long as broad (Fig. 2). Face very finely granulate, with very fine punctures. Frons smooth, weakly shining, with very fine or indistinct punctures. Vertex and temple smooth, very finely punctate, but punctures on temple sparser. Occipital carina mediodorsally absent.

Mesosoma compressed laterally, mostly finely granulate (partly almost smooth), dull, without distinct punctures. Notaulus as very strong, raised carina. Foveate groove situated in anterior part of mesopleuron, weakly impressed, broad and rugulose. Propodeum mediodorsally impressed, with basal area indistinct (because rugulose); basal part of propodeum about 0.26 times as long as apical area. Apical area long and narrow, rounded anteriorly (Fig. 5), rather strongly impressed along midline.

Wings poorly preserved, venation only partly distinguishable. Fore wing with second recurrent vein entirely absent, probably somewhat antefurcal. Metacarp almost reaching apex of fore wing. First abscissa of radius arcuate, shorter than width of pterostigma. Brachial cell probably open posteriorly. Hind wing with nervellus slanted $30-35^{\circ}$ from horizontal line. Legs slender; hind femur 4.0 times as long as broad. Tarsal claws very slender, weakly curved.

First tergite very slender, 5.6 times as long as posteriorly broad, more or less entirely smooth, round in crosssection, its upper margin in lateral view straight in basal 0.6 and weakly curved in apical 0.4. Second tergite 3.5 times as long as anteriorly broad. Thyridial depression long and narrow. Ovipositor short and strongly upcurved (Fig. 4), its sheath about as long as first tergite.

Head and mesosoma brownish black. Palpi, mandible (except extreme apex) and lower 0.4 of clypeus brownish yellow. Antenna yellow-brown basally to dark brown apically. Tegula brown. Pterostigma pale brown. Legs brownish yellow; mid coxa slightly brownish, hind coxa entirely brown. Metasoma brown with lateral yellowish marks.

Male. Unknown.

Etymology. From the type locality, Budongo Forest.

Distribution. Uganda.

Diaparsis (Diaparsis) interstitialis Khalaim, 2013

Material examined. Cameroun: 1 female (BMNH), NKoemvon, 4-18.V.1980 (Ms. D. Jackson coll.). Zimbabwe: 1 female (BMNH), Salisbury, Chishawasha, II.1981 (A. Watsham coll.).

Distribution. *Cameroun, *Zimbabwe, South Africa. 


\section{Diaparsis (Diaparsis) inusitata Khalaim, 2013}

Material examined. Cameroun: 1 female (BMNH), NKoemvon, VII-VIII.1979 (Ms. D. Jackson coll.). 1 female (ZISP), same data, but 19-30.XI; 1 female, 2 males (1 female and 1 male in BMNH, 1 male in ZISP), same data, but 30.XI20.XII. KENYA: 1 female (BMNH), Nairobi, XI.1979 (M.C. Croft coll.).

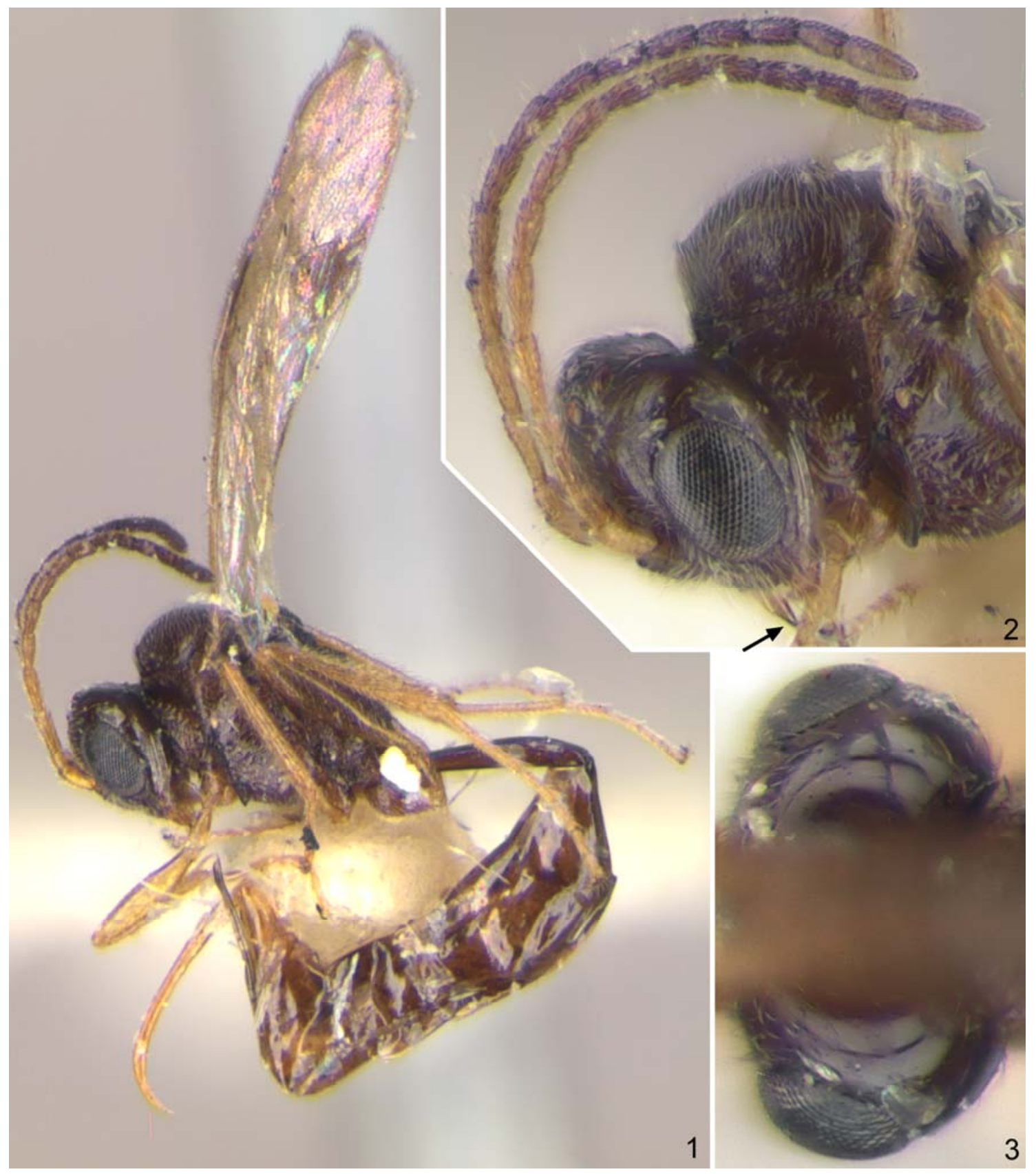

Figs 1-3. Allophrys budongoana sp. n., holotype, female: 1 - habitus, lateral view; 2 - head with antennae and anterior part of mesosoma, lateral view; 3 - head, dorsal view. 


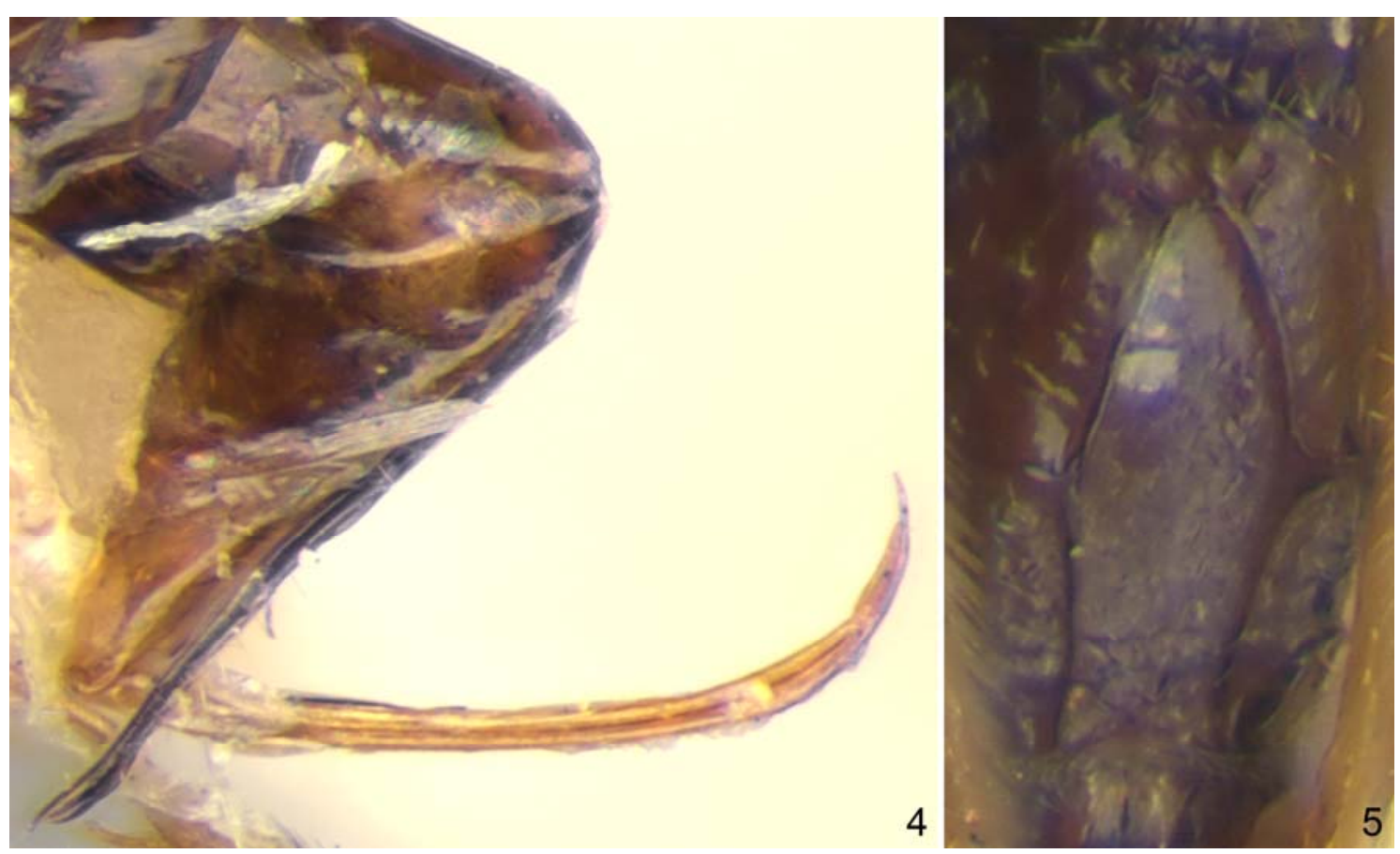

Figs 4, 5. Allophrys budongoana sp. n., holotype, female: 4 - apex of metasoma with ovipositor, lateral view; 5 - propodeum, dorso-posterior view.

Description. Male (first record). Malar space about as long as basal width of mandible. Flagellum distinctly tapered toward apex, with 24-26 flagellomeres. One male has second recurrent vein distinctly antefurcal. Second tergite almost twice as long as broad anteriorly. Otherwise similar to female.

Distribution. *Cameroun, *Kenya, Uganda.

\section{Diaparsis (Diaparsis) mostovskii Khalaim, 2013}

Material examined. Cameroun: 2 females (BMNH), NKoemvon, VII-VIII.1979 (Ms. D. Jackson coll.). 2 females (BMNH, ZISP), same data, but 19-30.XI. Ethiopia (“Abyssinia”): 1 male (BMNH), Mt. Zuguála, in crater, circa $9000 \mathrm{ft}$. (=2745 m), 26.X.1926 (J. Omer Cooper coll.).

Distribution. *Ethiopia, *Cameroun, South Africa.

\section{Diaparsis (Diaparsis) nebulosa sp. $\mathbf{n}$.}

(Figs 6-12)

Type material. Holotype: female (BMNH), Cameroun, NKoemvon, 21.I-6.II.1980 (Ms. D. Jackson coll.).

Paratype. Cameroun: 1 female (ZISP), same data as in holotype, but 30.XI-20.XII.1979.

Comparison. Similar to D. abstata Khalaim in structure and coloration, but differs by the flagellum of antenna with conspicuous white subapical band (Fig. 6), longer malar space, strongly punctate head and mesosoma (Figs 8, 9) and shorter foveate groove of mesopleuron (Fig. 8).

Description. F e m a le. Body length $3.5 \mathrm{~mm}$. Fore wing length $2.8 \mathrm{~mm}$.

Head straightly and strongly narrowed behind eyes in dorsal view; temple 0.38 times as long as eye width (Fig. 7). Flagellum of antenna distinctly tappered towards apex, with 25-26 flagellomeres; subbasal flagellomeres 1.4-1.5 times as long as broad, subapical flagellomeres slightly elongate to square. Mandible slender, with upper tooth much longer than lower tooth (lower tooth very small). Malar space $0.6-0.7$ times as long as basal width of mandible. Clypeus 2.5 times as broad as long, slightly convex in lateral view, mostly smooth, punctate in upper 0.6 and very finely granulate near its upper 


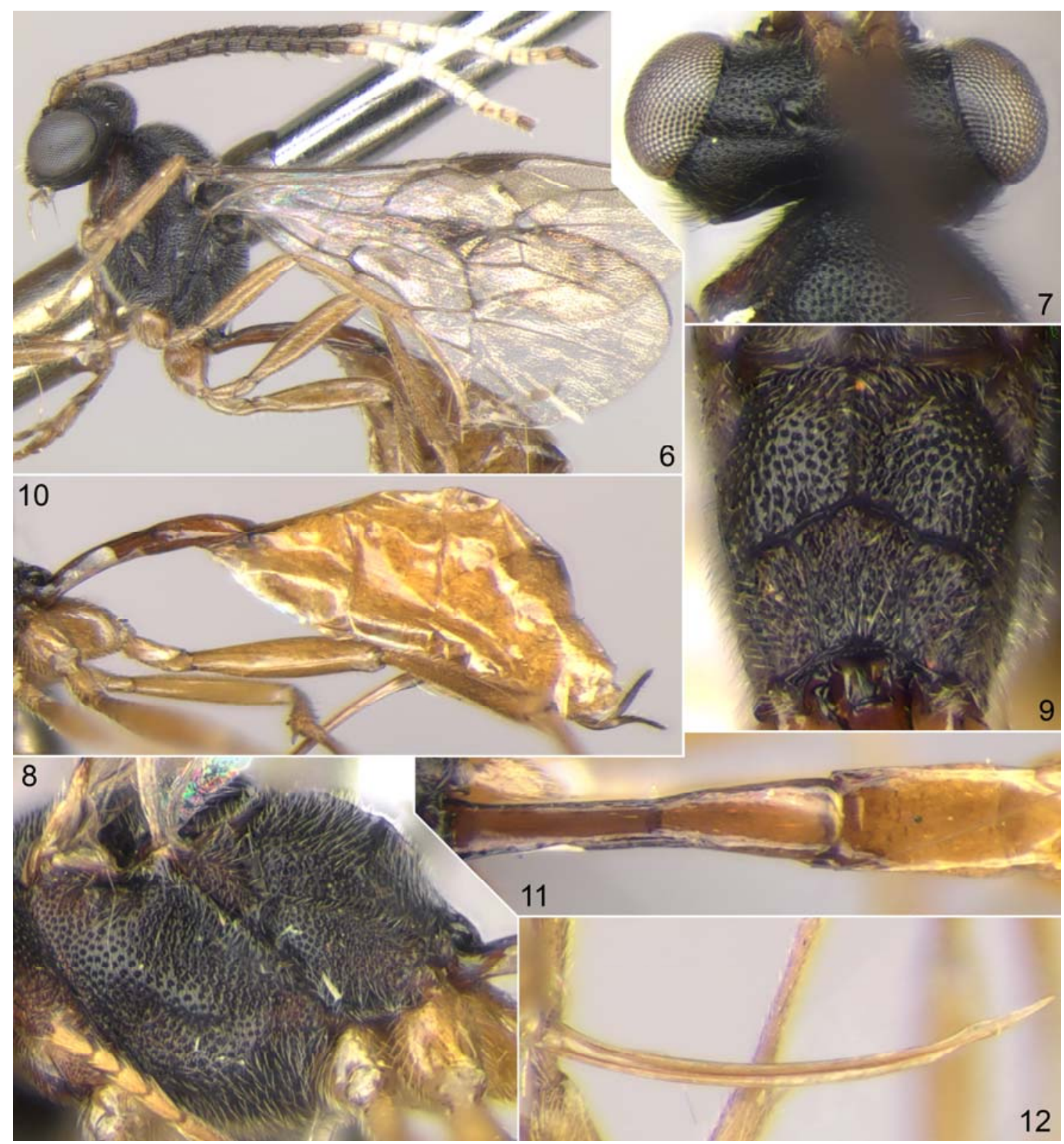

Figs 6-12. Diaparsis (Diaparsis) nebulosa sp. n., female (6, 7 - paratype; 8-12 - holotype): 6 - habitus (without apex of metasoma), lateral view; 7 - head, dorsal view; 8 - mesosoma, lateral view; 9 - propodeum, dorsal view; 10 - metasoma, lateral view; 11 - first and second tergites, dorsal view; 12 - ovipositor, lateral view.

margin. Face and frons finely granulate, dull, with very dense distinct punctures; distance between punctures mostly shorter than diameter of puncture. Vertex and temple finely granulate, dull (temple centrally almost smooth), with fine and moderately dense punctures (Fig. 7). Occipital carina complete. Hypostomal carina absent.

Mesosoma with mesoscutum, mesopleuron and dorsolateral area of propodeum finely granulate, dull, with very dense and distinct punctures (distance between punctures much shorter than diameter of puncture) (Figs 8, 9). Notaulus absent. Foveate groove not especially deep, situated almost in center of mesopleuron, upcurved anteriorly, wide and with transverse wrinkles. Propodeal spiracle small, separated from pleural carina by 2.5 diameters of spiracle. Propodeum with all carinae well developed; basal keel as long as apical area (Fig. 9); apical area very broad, flat, anteriorly somewhat pointed (Fig. 9); apical longitudinal carinae anteriorly reaching transverse carina. 
Fore wing with first abscissa of radius almost straight, somewhat longer than width of pterostigma. Metacarp reaching apex of fore wing. Second recurrent vein distinctly postfurcal. Intercubitus shorter than abscissa of cubitus between intercubitus and second recurrent vein. Hind wing with nervellus reclivous, slanted at $15^{\circ}$. Legs slender. Hind femur 4.9 times as long as broad. Spurs of hind tibia straight. Tarsal claws slender, distinctly curved, not pectinate.

Tergite 1 of metasoma slender, more or less round in cross-section, 4.7 times as long as posteriorly broad, with petiole striate laterally (holotype) or laterally and dorsally (paratype); glymma weak, situated slightly behind center of first tergite (Fig. 10). Second tergite about twice as long as anteriorly broad (Fig. 11); thyridial depression 2.5 times as long as broad. Ovipositor short, weakly upcurved, with weak and broad dorsal subapical depression (Fig. 12); sheath 0.65 times as long as first tergite.

Head black. Palpi, mandible (except blackish teeth), lower 0.3 of clypeus and tegula brownish yellow. Antenna with scape, pedicel and base of flagellum brownish yellow (holotype) or brown (paratype); flagellum blackish with subapical white band that covers flagellomeres 14 to 23 (Fig. 6). Pterostigma brown. First metasomal segment pale brown. Metasoma behind first tergite entirely brownish yellow (holotype) or partly brown dorsally (paratype).

Male. Unknown.

Etymology. From the Latin nebulosus (misty, foggy).

Distribution. Cameroun.

Diaparsis (Diaparsis) probleformis Khalaim, 2013

Material examined. Kenya: 1 female (BMNH), Nairobi, XI.1979 (M.C. Croft coll.). Namibia: 1 female (BMNH), Okahandja, 10-16.II.1928 (R.E. Turner coll.).

Distribution. *Kenya, *Namibia, South Africa.

Diaparsis (Diaparsis) voluptuosa Khalaim, 2013

Material examined. Zimbabwe ("Rhodesia"): 1 female (BMNH), Salisbury, Chishawasha, IV.1978 (A. Watsham coll.).

Distribution. *Zimbabwe, Tanzania, South Africa.

\section{Probles (Euporizon) kipyatkovi sp. n.}

(Figs 13-17) sham coll.).

Type material. Holotype: female (BMNH), Zimbabwe ("Rhodesia”), Salisbury, Chishawasha, V.1978 (A. Wat-

Paratypes. South Africa, KwaZulu-Natal: 1 female (SAMC), Pietermaritzburg, Winterskloof, $29^{\circ} 34.56^{\prime} \mathrm{S}$ $30^{\circ} 17.40^{\prime}$ E, 1085 m, yellow pan trap, 15-19.II.2007 (M. Mostovski and V. Kolyada coll.). 2 females (SAMC, ZISP), same locality and altitude, Malaise trap, 20.IV-1.IX and 2.IX-12.XI.2007 (M. Mostovski coll.). 1 female (ZISP), Pietermaritzburg, Karkloof, $29^{\circ} 19.1^{\prime} \mathrm{S} 30^{\circ} 15.5^{\prime} \mathrm{E}, 1325 \mathrm{~m}$, yellow pan trap, 22.I-6.II.2007 (M. Mostovski and V. Kolyada coll.). 1 female (ZISP), Pietermaritzburg, Hilton Garden, Malaise trap, 4-23.X.2004 (M. Mostovski coll.). 1 female (BMNH), Cathedral Peak Nature Reserve, Rainbow Gorge, 2857.60'S 29¹3.61'E, 1480 m, Malaise trap, 25.XI-12.XII.2005 (M. Mostovski coll.).

Comparison. Differs from all known species of the genus by the flagellum with white apical band (Fig. 15). This species is also characterized by the propodeum with basal area long and the apical area very broad.

Description. F e m a le (holotype). Body length $2.2 \mathrm{~mm}$. Fore wing length $2.1 \mathrm{~mm}$.

Head rounded behind eyes in dorsal view; temple 0.55 times as long as eye width. Flagellum of antenna weakly tappered towards apex, with 19 flagellomeres; flagellomeres 2 and 3 about 1.8-1.9, subapical flagellomere 1.4 times as long as broad (Fig. 15). Mandible with upper and lower margins mostly subparallel, upper tooth distinctly longer than lower tooth. Malar space 0.6 times as long as basal width of mandible. Clypeus wide, about 3.5 times as broad as long, smooth, with few fine punctures near its upper and lower margins. Face and frons finely granulate, dull, impunctate. Vertex very finely granulate, weakly shining, impunctate. Temple smooth and shining. Occipital carina complete. Hypostomal carina absent.

Mesosoma finely granulate, dull to weakly shining, impunctate; mesopleuron medially and ventrally smooth. Notaulus as moderately deep depression distad of anterolateral margin of mesoscutum. Foveate groove situated in anterior 0.7 of mesopleuron, oblique (slanted at $45^{\circ}$ ), rather narrow and sharp, with fine transverse wrinkles. Propodeal spiracle small, separated from pleural carina by almost 3.0 diameters of spiracle. Propodeum with distinct rectangular basal area (basal longi- 


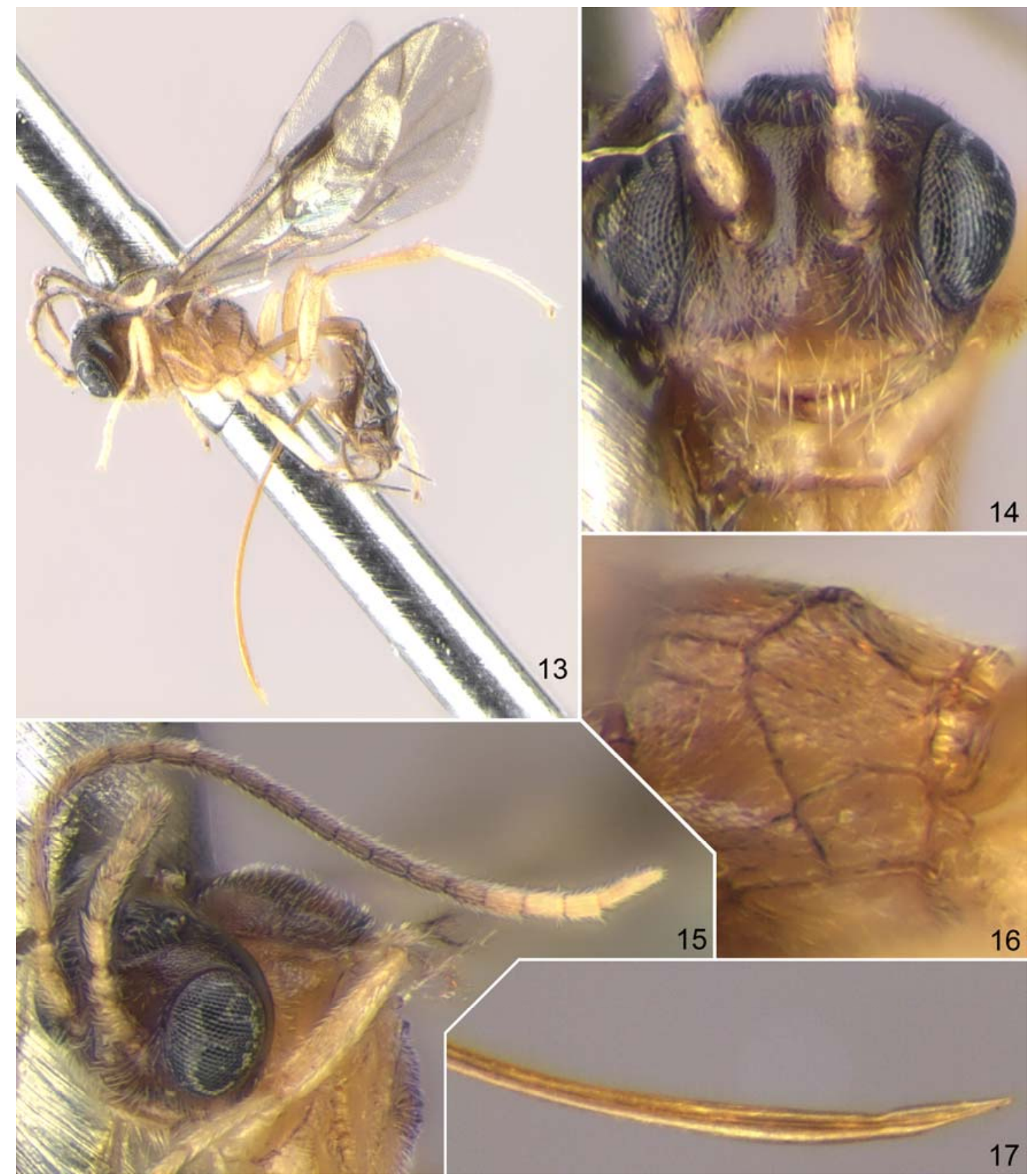

Figs 13-17. Probles (Euporizon) kipyatkovi sp. n., holotype, female: 13 - habitus, lateral view; 14 - head, frontal view; 15 - head with antenna and anterior part of mesosoma, antero-lateral view; 16 - propodeum, dorso-postero-lateral view; 17 - apex of ovipositor, lateral view.

tudinal carinae more or less parallel), this area 0.6 times as long as apical area (Fig. 16); apical area broad, flat; apical longitudinal carinae anteriorly reaching transverse carina.

First abscissa of radius straight, longer than width of pterostigma. Metacarp not reaching apex of fore wing (Fig. 13). Second recurrent vein distinctly postfurcal. Intercubitus very short. Hind wing with nervellus reclivous, slanted at $20-30^{\circ}$. Legs slender. Hind femur 4.3 times as long as broad. Spurs of hind tibia almost straight. Tarsal claws not pectinate.

Tergite 1 of metasoma 3.8 times as long as posteriorly broad, with petiole partly striate dorsally and laterally; glymma situated behind centre of first tergite, joining to ventral part of postpetiole by distinct furrow. Second tergite 
1.4 times as long as anteriorly broad; thyridial depression about twice as long as broad. Ovipositor long, weakly and evenly upcurved, with weak and wide dorsal subapical depression (Fig. 17); sheath about 2.6 times as long as first tergite.

Head brownish black, paler ventrally and darker dorsally. Palpi and mandible (teeth reddish) yellow. Clypeus mostly yellow, brownish near its upper margin. Antenna blackish, basally yellowish-brown, apical 3 to 4 flagellomeres white (Fig. 15). Mesosoma predominantly brownish yellow, mesoscutum brown, propodeum dorsally slightly darkened. Pterostigma brown. Legs entirely yellow. First metasomal segment yellowish basally to pae brown apically. Metasoma behind tergite 1 brown to dark brown.

Male. Unknown.

Variation. Coloration varied, usually mesosoma dorsally darker than ventrally. Flagellum with 19-20 flagellomeres; subbasal flagellomeres sometimes very slender, almost 3.0 times as long as broad. Malar space 0.6-0.9 times as long as basal width of mandible. Propodeum (especially its apical area) sometimes partly rugulose and basal area weakly defined or indistinct. Kipyatkov.

Etymology. Named in remembrance of the Russian expert in Formicidae, Professor Vladilen E.

Distribution. Zimbabwe, South Africa.

\section{Acknowledgements}

I am thankful to Dr. Gavin Broad (BMNH) and Dr. Mike Mostovski (SAMC) for loan of valuable material. This work was supported by the grant no. 13-04-00026 of the Russian Foundation for Basic Research.

\section{References}

Khala im A.I. 2007. First records of Meggoleus, Heterocola and Phradis (Hymenoptera: Ichneumonidae: Tersilochinae) from the Afrotropical region, with description of four new species. African Invertebrates, 48(2): 101-110.

K h a 1 a i m A.I. 2009. South African species of Aneuclis Förster, 1869 (Hymenoptera: Ichneumonidae: Tersilochinae). African Invertebrates, 50(1): 123-136.

K hal a im A.I. 2010. To the study of Afrotropical species of the genus Aneuclis Förster, 1869 (Hymenoptera: Ichneumonidae: Tersilochinae). Zoosystematica Rossica, 19(1): 120-123.

Khala im A.I. 2011. Tersilochinae of South, Southeast and East Asia, excluding Mongolia and Japan (Hymenoptera: Ichneumonidae). Zoosystematica Rossica, 20(2): 96-148.

Khala im A.I. 2013a. Afrotropical species of Diaparsis Förster, 1869 (Hymenoptera: Ichneumonidae: Tersilochinae). African Invertebrates, 54(1): 127-159.

Khala im A.I. 2013b. Discovery of the South African fauna of Allophrys Förster (Hymenoptera: Ichneumonidae: Tersicochinae). Zootaxa, 3701(3): 329-343.

T ow ne s H.K. 1969. The genera of Ichneumonidae, Part 1. Memoirs of the American Entomological Institute, 11: 1-300.

To w n e s H.K. 1971. The genera of Ichneumonidae, Part 4. Memoirs of the American Entomological Institute, 17: 1-372. 